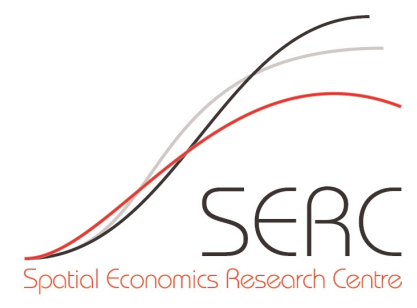

SERC DISCUSSION PAPER 123

\title{
The Causal Effect of Credit Guarantees for SMEs:
}

\section{Evidence from Italy}

Alessio D'Ignazio (Research Department, Bank of Italy)

Carlo Menon (OECD, Structural Policy Division, Directorate for Science, Technology and Industry)

December 2012 
This work is part of the research programme of the independent UK Spatial Economics Research Centre funded by a grant from the Economic and Social Research Council (ESRC), Department for Business, Innovation \& Skills (BIS) and the Welsh Assembly Government. The support of the funders is acknowledged. The views expressed are those of the authors and do not represent the views of the funders.

(C) A. D'Ignazio and C. Menon, submitted 2012 


\section{The Causal Effect of Credit Guarantees for SMEs: Evidence From Italy}

\section{Alessio D'Ignazio and Carlo Menon}

\section{December 2012}

* Research Department, Bank of Italy

** OECD, Structural Policy Division, Directorate for Science, Technology and Industry

Acknowledgements

We wish to thank the following for their valuable comments and suggestions: Mario D. Amore, Raffaello Bronzini, Guido de Blasio, Chiara Criscuolo, Lucia Cusmano, Paolo Finaldi Russo, Steve Gibbons, Giorgio Gobbi, Silvia G. Magri, Sabrina Pastorelli, Paolo Pinotti, Massimo Sbracia, Ugo Trivellato, Gregory Udell, two anonymous referees, and participants at the OECD/DSTI internal seminars. The usual disclaimer applies. The views expressed in the paper are those of the authors and do not necessarily reflect those of the Bank of Italy or the OECD. 


\begin{abstract}
$\underline{\text { Abstract }}$
We evaluate the effectiveness of a partial credit guarantee program implemented in a large Italian region using unique microdata from a broad set of firms. Our results show that the policy was effective to the extent that it resulted in an improved financial condition for the beneficiary firms. While the total amount of bank debt was unaffected, firms showed a significant increase in the long-term component. Furthermore, targeted firms benefited from a substantial decrease in interest rates. On the other hand, there is some evidence that the probability of default increases as a consequence of the treatment, although the effect is only marginally significant. There are, instead, no effects on the real outcomes.
\end{abstract}

JEL classifications: G2, H2, O16

Keywords: Financial subsidies, credit constraints, banking 


\section{Introduction}

Guarantee schemes are widespread in both developed and developing economies, as they are considered as an effective instrument for improving access to financial assets for entrepreneurial activities. They are often funded by public institutions, and their implementation is frequently listed among the policy recommendations of international organizations (OECD (2011), European Commission (2011a)). The popularity of guarantee schemes is due to the multiplicative effects embedded in such policies, their capacity to move private capital, and the possibility of recovering a large share of the public fund at the end of the program.

Despite their popularity, economic theory is not conclusive on the net effect of credit guarantee schemes on firms' finance. The actual effects of these programs is ultimately an empirical question, but there is very little evidence available so far. This paper tries to fill this gap, by estimating the causal effect of a credit guarantee scheme implemented in Italy in 2008. Compared to the existing empirical literature, which is mainly based on difference-indifferences estimators or on propensity score matching, this paper has the advantage of relying on more advanced estimation methods, arguably requiring weaker assumptions and therefore providing more ground for the consistency of the estimated treatment effects.

The identification of the policy's net effects is indeed challenging, since treated and untreated firms may be intrinsically different, and this difference may be unobservable to us. Ideally, the program's effectiveness is measured by the difference in average outcome of the same group of firms with and without treatment at the same time, respectively. Such a counterfactual scenario is obviously unfeasible, but we obtain a consistent estimate of treatment effects via instrumental variable estimation. The exogenous source of treatment is derived from some peculiar features of the guarantee scheme, combined with the unforeseen acquisition of a local bank by one of the largest Italian banking groups. The validity of the IV procedure is further reinforced by the inclusion of a wide set of fixed effects and additional controls. Furthermore, the estimates survive two demanding falsification tests.

We find that the program had no impact on the volume of firms' bank debt, while increasing the amount of long-term debt and decreasing the interest rate paid by firms. The probability of default increased slightly. All other firm-level variables were unaffected; in particular, we were not able to find significant effects on firms' balance sheets, suggesting that the improved financial structure did not have a direct "real" effect, at least in the short term. Specifications not tackling the endogeneity of the policy fail to recognize most of these outcomes, and therefore lead to erroneous conclusions about its effects.

A further element of interest is that our analysis focuses on the "credit crunch" period, when credit constraints for firms were particularly strin- 
gent. Therefore, even if the design of the policy was not explicitly targeting financially-constrained firms, the advent of the credit-crunch significantly rationed the credit supply to all eligible firms. This also leaves out some potential endogeneity of the policy, since the crunch was surely unexpected when the policy was designed, in the 2006 .

\section{SMEs lending and credit guarantees schemes}

The slowing down of economic growth since the turn of the century, the new challenges of globalisation, the fear of de-industrialisation and the recent financial crisis have renewed interest in industrial policies in Europe. Industrial policies are often based on a mix of subsidies, which may take the following forms: grants, defined as monetary paymentstaking the form of a lump sum, which are proportional either to the amount of the investment or to the costs borne by the firm for a given project; tax incentives, taking either the form of tax exemptions/reductions or that of a tax credit; subsidised loans and public loans, mostly aimed at reducing the interest rate paid by firms (although the incentive might also involve postponement of repayments or a more favourable evaluation of creditworthiness); and guarantees, in the case in which the public authority absorbs the (partial) insolvency risk of a borrower, allowing otherwise constrained firms to access credit, and riskybut-creditworthy firms to get financing at a lower cost.

Furthermore, the rationale for the introduction of firm subsidies underlines the general consensus on both the importance of the role of SMEs in economies and on the difficulties they face in accessing credit (European Commission, 2011b). The latter depends on the higher costs of small-scale lending, the lack of collateral, the reduced reliability of (often non audited) financial statements, asymmetric information, and the limited liability structure of most SMEs (Beck, Klapper and Mendoza, 2008). Credit guarantees aim to offset such situations, improving both the access to credit and the terms of loans. On the other hand, the main argument against firm subsidies builds on their potential distorsive effects (de Meza (2002), Vogel and Adams (1997)) and on the fact that these policies tend to replace the markets rather than fix the underlying problems causing credit restrictions for SMEs. In the case of credit guarantees the distorsive effect is considered smaller than the other forms of aid, while the most serious critiques consist in their potential for moral hazard, both from the firms' and from the banks' perspective, although this aspect is still debated. Again, an additional advantage of credit guarantee schemes is the low initial cost, and the fact that large losses are incurred only in the event of multiple bankruptcies or bank failures (Beck et al., 2008).

Broadly speaking, we can distinguish between two main typologies of credit guarantees schemes: (1) Mutual guarantee associations (e.g., Confidi 
in Italy): private societies formed by potential borrowers with limited access to bank loans that share their debt risk. However, they suffer from an adverse selection problem, as firms that consider joining the association know that the schemes attract more risky firms. (2) Public guarantee schemes, funded by regional or national authorities: run either by an administrative government unit (e.g. development agencies, ministries, the central bank or publicly-owned banks) or by a legally separate credit guarantee organisation. Resources usually take the form of periodic appropriations, i.e. regular subsidies, or of a fixed fund. Public guarantee schemes still represent the majority in low-income countries, while mutual guarantees are more widely used in high-income countries (Beck et al., 2008).

Theoretically, the effect of the introduction of a credit guarantee scheme (CGS, hereinafter) is ambiguous. In the case of firms unable to meet the collateral requirements of the bank, a CGS can lead to more credit being granted to the firm. Moreover, by reducing the informational asymmetries between a firm and a bank, the presence of a guarantee can lead to lower interest rates being paid by the borrower, hence reducing moral hazard and adverse selection problems. Meyer and Nagarajan (1996) have argued that credit guarantees can lead to a learning process, where banks discover that borrowers benefiting from the guarantee are not as risky and unprofitable as initially expected and become willing to provide loans to them in the future without a guarantee. Riding, Madill and Haines (2007) are of a similar view. On the other hand, a CGS might equally lead to riskier behavior by both the entrepreneur and the bank. In particular, if the CGS enforces entrepreneur's limited liability (i.e., if banks can only rely on a CGS), then the firm might be willing to adopt riskier strategies than those adopted under normal circumstances (Lelarge, Sraer and Thesmar, 2008). From a bank's point of view, if the share of the loan covered by the guarantee is too large, the incentive to undertake a tough screening might become smaller (Benavente, Galetovic and Sanhueza, 2006). Another potential distortion is the fact that banks might be induced to be too quick in writing off loans backed by the guarantee and hence exerting little effort to collect the outstanding share of the loan 1

The empirical evidence on the effectiveness of a CGS is both scarce and mixed. Hancock, Peek and Wilcox (2007) focus on the impact of credit guarantees provided in the US by the Small Business Administration, finding

\footnotetext{
${ }^{1}$ Vogel and Adams (1997) point at two sources of substitution that would diminish the effect of the guarantees and that would result in an overestimation of the additionality if the analysis were carried out at the bank level. The first one is intra-portfolio substitution: lenders may redefine the purpose of existing loans to qualify borrowers for a loan guarantee, or they might employ 'column-shifting', moving distressed loans into the guaranteed portfolio. A second one is inter-lender substitution: enterprises serviced by other banks are captured by those banks operating under a guarantee scheme. Analysis at the firm level, however, is less tricky.
} 
that the disbursement of guarantees led to an increase in both firms' output and employment. Lelarge et al. (2008) studied the guarantee program Sofaris (also known as Ose Garantie), carried out in France. They find that credit additionality holds in the intensive margin, while there are no effects on the extensive margin. In addition, the program appeared to have induced more risk taking from the beneficiary firms. Kang and Heshmati (2008) studied the impact of two CGSs implemented in Korea, focusing on firm sales, productivity, and employment. They find only weak evidence in favour of credit guarantees, whose effectiveness was lowered, among other things, by the fact that they were mainly employed to support financially unconstrained firms. Zecchini and Ventura (2009) study the effectiveness of a publicly funded guarantee scheme for SMEs implemented in Italy. They find that the guarantee resulted in a greater amount of bank loans being granted to the firms; this effect, however, was rather small in size. ${ }^{2}$ The public guarantee also lowered the costs borne by the firms. However, they noticed that the scheme did not necessarily target the most financially disadvantaged firms: there was no screening to assess whether a loan proposed by a bank to the Fund would have been granted even in the absence of a guarantee. Hence, the pattern of guarantees could reflect essentially bank lending decisions, rather than SMEs' potential needs. Columba, Gambacorta and Mistrulli (2009) investigate the impact of the mutual guarantee institutions in Italy (Confidi) and show that small firms affiliated to the Confidi pay lower interest rates on loan contracts which are not backed by mutual guarantees with respect to similar firms. Their finding is consistent with the view that mutual guarantee instututions are better at screening and monitoring borrowers than banks are. In a more recent paper, Mistrulli and Vacca (2011) find that mutual guarantee institutions played a role in avoiding a break-up in credit flows to affiliated firms during the crisis. Moreover, affiliated firms also faced lower interest rates with respect to similar firms. On the other hand, the deterioration in credit quality during the crisis has been more intense for customers with guarantees from Confidi.

\section{The policy}

In this paper we focus on a partial credit guarantee regional program devised in 2006 in Italy to improve SMEs' access to credit. The program, which started operating in 2008 in a large Italian region, benefits from a regional fund with an endowment of approximately $€ 20$ million per year, managed by the regional administrative body.

\footnotetext{
${ }^{2}$ Other guarantee schemes include: Sowalfin (Belgium); Tempte SA (Greece); Besluit Borgstelling Midden en Klein Bedrijf (Netherlands); Agrogarante; Garval; Lisgarante; MCGF; Norgarante (Portugal); ISBA; SGR; Sociedad de Garantia Reciproca; Transaval S.G.R; (Spain); ALMI Foretagspartner AB (Sweden); and CSC Centrale Suisse de Cautionnement (Switzerland).
} 
Each firm loan involves an agreement between the region and a private covenant bank. Before conceding the loan, both the region and the covenant bank proceed separately to a credit screening. Loans backed by the guarantee typically have a 5 years amortization schedule, which follows a grace period of variable length. The protection individually offered by the region on each loan covers up to 80 per cent of the losses in case of default of the firm or write-off of the loan; these occurrences are referred as a 'credit event'. Importantly, only a few bank groups act as covenant banks. While subsidised loans are not formally restricted to firms lent by covenant banks, these firms had a first-mover and information advantage which significantly increased their probability of enrolling in the program.

So far, the program has consisted of several waves: we focus on the first one, which began in 2008, since it leaves us with a sufficiently long post-intervention window 3 The first wave saw the participation of just one covenant bank.

Eligible firms include all SMEs headquartered in the region undertaking the policy, with a total turnover of between $€ 1$ million and $€ 43$ million in 2007 , or of under $€ 50$ million and less than 250 employees (the upper bound is set by the definition of SME given by the European Commission in the EU Recommendation 2003/361). The turnover's lower bound, however, is € 500,000 for the firms belonging to a set of sectors considered 'prioritary'. Beneficiary firms must also be eligible for the application of the National Fund by Law 662/96 (i.e., SMEs according to the definition in European Commission Recommendation 2003/361, which are not in economic or financial distress, belonging to any sector but those considered "sensitive", such as agriculture, transport, shipbuilding, motor vehicles, and so on).

\subsection{Aims of the policy and expected outputs}

The effectiveness of the partial credit guarantee scheme can be assessed from various viewpoints. First, did this measure lead to an increase in the amount of credit granted to the beneficiary firms? To the extent that financially constrained firms could obtain guarantees at a cost lower than the market one, they could obtain more credit. Second, did the CGS result in lower interest rates? Third, did the CGS improve the financial structure of the beneficiary firms? Even if there is no credit additionality, replacing shortterm debt with long-term debt can improve the firm's financial structure, eventually lowering their probability of default. Fourth, did the CGS lead to an increase in the level of output, investments and employment? These are indirect effects in firm performance which could originate from any of the direct mechanisms listed above, namely a larger amount of credit or a less onerous debt structure.

\footnotetext{
${ }^{3}$ Firms treated in following waves of the program are excluded from the sample.
} 
Although the actual beneficiaries of the program are both banks and firms, in this paper we focus mainly on firms, since they were the target of the policy maker, and we have a clear a-priori idea of the expected outcome.

\section{Data}

Our empirical exercises benefit from a unique and very rich database, a panel of about 9,000 firms located in the region where the policy was implemented and in the three neighbouring regions, which we use to further populate the control group. The dataset is built from three different sources and covers the period 2003-2010

We use the official dataset maintained by the regional administrative body, including the full list of beneficiary firms. For each firm the dataset reports a broad set of information, such as: the date of the guarantee approval, the name of the covenant bank, the amount of guaranteed loans and that of the guarantee, the date of the first disbursement, the riskiness (in the application year) of the firm and several balance sheet variables referring to the year preceding the first disbursement.

The guarantee scheme that we focus on involved about 200 firms. We merge this dataset with two additional sources of information: the Central Credit Register (CCR) maintained at the Bank of Italy and the Cerved dataset on Italian corporations.

The CCR ${ }^{4}$ provides bank-firm level information on a large set of financial variables. We are interested, in particular, in the amount of credit from banks, the interest rate and the probability of default. Since our identification strategy relies on bank-firm relationship characteristics, we collect end-of-year data on loans at the bank-firm level.

We also gather firm balance-sheet information from the Cerved archive, containing data on all Italian corporations, covering the period 2003-2010. We use this information both to improve our identification strategy and to investigate the impact of the guarantee scheme on real outcomes. All the variables are measured at the end of the year.

We focus on seven dependent variables, in order to assess both the direct and indirect effects of the policy:

- Long-term bank debt: total stock of long-term loans owned by the firm (irrespectively on the lending bank), expressed in log.

- Total bank debt: total stock of bank loans, including both short-term loans and long-term loans, expressed in log.

\footnotetext{
${ }^{4}$ According to the Italian Banking Regulation 'for each borrower, financial intermediaries supervised by the Bank of Italy have to report to the CCR, on a monthly basis, the amount of each loan, either granted or disbursed by banks, for all loans exceeding a given threshold' (the threshold was $€ 75,000$ until 31 December 2008).
} 
- Share of long-term debt over total debt.

- Interest rate: nominal interest rate paid by the firm on medium and long-term bank loans.

- Probability of default: we consider bad loans from all the outstanding bank credit to borrowers considered insolvent. The variable is binary and is equal to one whenever at least one lending relationship involving the given firm is listed as 'bad' by the bank.

- Trade debts: debts towards suppliers providing goods and services necessary to the production cycle and tangible-intangible assets. All variables are measured at the end of the year.

- Investments: yearly growth rate of fixed assets.

In order to estimate our model we introduce firm fixed effects. To control for time-variant firm characteristics we include a set of lagged variables, aimed at controlling for firm riskiness (by means of dummies based on the z-score, which increase with the probability that a firm becomes insolvent), the positioning of the firm in the credit market (by means of the number of lending banks), firm age, and firm performance (measured by turnover and total assets).

To limit selection, we restricted the sample to firms that did not enter or exit in the period 2005-2010.5 Table 1 reports the descriptive statistics of the firms in the sample.

\section{Empirical strategy and identification}

The aim of the paper is to assess the impact of the credit guarantee scheme on a number of firm-level variables. Formally, we estimate the treatment effect with the following regression model:

$$
y_{i t m r}=\alpha+\beta T_{i t}+X_{i t} \gamma+\delta_{i}+\mu_{m t}+\rho_{r t}+\epsilon_{i t}
$$

where $\mathrm{y}$ is the potential output of interest, $\mathrm{T}$ is a treatment dummy, $\mathrm{X}$ is a set of firm-specific time-variant controls, and $\delta, \mu$, and $\rho$ are firm, year, bank and region fixed effects, respectively; $i$ indexes firms, $t$ years, $m$ lending banks, and $r$ regions. Bank and region fixed effects are allowed to change over time. The model is estimated based on yearly data from 2005 to 2010 .

If treatment were randomly assigned conditional on observables, the parameter $\beta$ would be the consistent estimate of the average treatment effect (ATE). However, the treatment dummy is likely to be correlated with the

\footnotetext{
${ }^{5}$ The closed sample also allows us to evaluate the persistence of the treatment effects over time and to minimize the selection bias due to spurious exits and entries, which may affect our database.
} 
error term, since firms are heterogeneous and some of their unobserved idiosyncratic characteristics may be correlated with both the outcome variable and the treatment dummy. This means that treated and untreated firms are systematically different, irrespective of the policy. We control for timeinvariant heterogeneity by means of individual fixed effects; however, to the extent that unobserved idiosyncratic factors are time-variant, our estimates are hardly consistent.

In particular, there are two main challenges to a consistent estimation of the treatment effect. First, the covenant bank may have been selected by local policy makers because of its special attitude towards local SMEs, or because of specific trends (e.g., shrinking employment) in its portfolio of funded firms; in turn, these factors may affect the program outcome. Second, firms selected by the bank - or self-selected - into the program may be intrinsically different from the average firm, e.g., they can be more credit-constrained. This is also likely to have an independent impact on the outcome variables.

We overcome these two challenges and reach identification by exploiting an exogenous event that involving the bank selected to operate the policy and a peculiar aspect of the Italian credit market.

The first key factor in our identification strategy is a M\&A operation affecting the covenant bank. The first wave of the guarantee scheme was planned in 2006 and involved only one covenant bank, namely a regional bank - which we will henceforth call 'bank A' - with a large share of loans in the region and limited penetration outside the regional boundaries. A few months before the program was actually implemented, at the beginning of 2008, bank A was acquired by one of the leading Italian (and European) banking groups previously completely unrelated to bank A, which we call 'bank B'.

Therefore, while it is likely that the original choice of the covenant bank A when the policy had been designed could be dependent on unobservable bank characteristics, bank B became a covenant bank only because of the M\&A operation, which was unexpected by regional policy makers. This rules out the possibility of a bias originating from a non-random selection of the covenant bank.

This alone, however, does not completely exclude the treatment and control groups being systematically different, either because treated firms are a specific selection of all firms funded by bank B, or because highly "motivated" firms may decide to change funding bank in order to enroll in the program, or because the policy maker was targeting bank A's portfolio of firms, rather than bank A itself.

Related to this concern, one characteristic of the Italian financial market contributing to our identification strategy is the stickiness of the firm-bank relationships. Italian firms tend to swap bank rarely, mainly because of high switching costs (Barone, Felici and Pagnini, 2011) and the importance of reputation for obtaining new credit. It follows that firms which were 
financed by bank B before the policy was planned were highly likely to still be customer of bank B when the policy had been implemented. As shown in the next section, at firm level the lagged creditor bank is a very good predictor of the current creditor bank.

The interactions of these two elements (the M\&A event and the stickiness of firm-bank relationships) provide a powerful source of exogenous treatment: firms that were funded by bank B were more likely to enroll in the program for reasons which are independent of the policy and unforeseen by the regional policy maker. Intuitively, the group of firms funded by bank B before the policy was planned became "randomly" very likely to enroll in the program. We therefore build an instrumental variable based on these conditions.

More precisely, the assumption we make to validate the exclusion restriction of our empirical strategy is that, conditional on firm characteristics and on firm, time, time-bank, and time-region fixed effects, the treatment outcome is independent of the firm being a customer of bank B before the policy was planned. In the next section of the paper, we will further support the validity of this assumption with a battery of falsification tests.

We thus estimate an exogenous treatment propensity for firms based on a dummy which is equal to one if the firm was lent by bank B before the PCG scheme had been designed, expecting that firms lent by bank B in year T-n have a higher propensity of being lent by bank B in year $T$, and therefore of belonging to the treatment group.

Furthermore, bank B, being one of the major Italian and European banking group, holds a large number of lending contracts in neighbouring regions, which allows to control for a time-variant bank fixed effect; this is a particularly powerful control, since Italian banks show little variability in their lending strategy across geographical areas (Bank of Italy, 2011).

In theory, we could simply use a dummy equal to one if the firm is lent by bank B at time $T-n$ as an instrument. However, given that the endogenous variable is binary, we opt for the "procedure 18.1" suggested by (Wooldridge, 2002) ${ }^{6}$, which has been proven to produce consistent estimators and asymptotically valid standard errors and test statistics, while increasing efficiency. The exogenous treatment propensity is thus estimated in the following way:

$$
\operatorname{Pr}\left(T_{i T}\right)=\alpha+\phi_{1} \text { Bank }_{t-3}+\text { Eligible }_{i t-3} \phi_{2}+X_{i 0} \phi_{3}+\varepsilon_{i T}
$$

where the probability of treatment in the year $T$ in which the program was implemented (2008) is a function of having a lending relationship with bank B three years earlier (i.e. in 2005, before the program was designed or announced) but no lending relationship with the covenant bank A, of being eligible three years earlier (in 2005, the year before the policy was announced;

\footnotetext{
${ }^{6}$ See, in particular, section 6.1 .1 and 18.4 .1
} 
the variable is a binary dummy), and on a set of firm-specific variables at time 0, i.e., the year in which the firm entered the sample (2004 or 2005). The model is estimated with a Probit regression only for the treatment year $T$.

The estimated propensity score subsequently becomes the instrumental variable in a two-stages least square estimation of model 1 .

We also perform a robustness test using the simpler binary instrument (equal to one if the firm had a lending relationship with bank B three years earlier, and if eligibility conditions were met the year before treatment). As expected, this second set of results are similar to the ones based on the exogenous treatment propensity, but less precise. The results are not reported here for the sake of brevity, but they are available from the author upon request.

By conditioning on bank-firm relationships at T-3 (year 2005), our empirical strategy implicitly evaluates the effect of the policy on firm credit in terms of the intensive margin only. In this paper we do not attempt to investigate the effect in terms of the extensive margin since the policy, by conditioning the application to the firms having reached a turnout greater than $€ 1$ million in 2007, de facto implicitly targets incumbent firms 7 .

\section{Results}

We find that the policy was effective to the extent that it resulted in an improved financial conditions for the beneficiary firms. While those results confirm that the total amount of bank debt was unaffected, treated firms showed a significant increase in the long-term component. Moreover, targeted firms benefited from a substantial decrease in interest rates. On the other hand, the program slightly affected the risk of moral hazard: the probability of default for a treated firm becomes larger than that of an otherwise identical untreated company in the two years following the treatment, while the impact is negligible if a longer period is considered. Finally, we observe only weak effects on the real outcomes: the policy had no significant impact on investments and trade debts.

We present these results in detail below, commenting on both OLS and IVE results. In every column reporting IVE results, the last row shows the Kleibergen-Paap Wald F-statistic of the corresponding first stage regression, which is always well above the weak instrument threshold calculated by Stock and Yogo (2005). The tables report the coefficient values; given that all variables are expressed in log, the coefficients correspond to elasticities.

- Long-term bank debt (table 2): the policy targeted long-term loans

\footnotetext{
${ }^{7}$ This is confirmed by our data: about 90 per cent of treated firms were already registered in the Credit Register in 2005. Hence, the impact of the policy at study in terms of the extensive margin appears barely relevant.
} 
directly, and indeed we find a positive effect. OLS estimates show that these increased by $36 \%$ on average in the first year, $33 \%$ over two years, and $30 \%$ over three years. The results for IVE coefficients are very similar: when the selection is controlled for, the effect is equal to $40 \%$ in the first year, $23 \%$ over two years, and $21 \%$ over three years.

- Total bank debt (table 3): OLS estimates suggest that the policy increased the volume of total bank debt too, since coefficients are significantly positive, and range from $17 \%$ (in the first year) to $12 \%$ (over three years). However, IVE coefficients are much smaller and not statically different from zero. In particular, the coefficient over three years is equal to -0.13 with a standard error of 0.09 . Therefore, once we control for endogenous selection in the treatment sample, substitution across time and type of debts cancels out the positive impact of the program on the volume of loans.

- The share of long-term bank debt over total bank debt (table 4): both OLS and IV estimates suggest that, in accordance with previous results, the share of long-term debt over total bank debt increases, suggesting that firms move towards a more balanced (and less costly) financing structure.

- Interest rates (table 5): since we consider the average interest rate paid by the firms on all operations, hence adjusting very slowly, we allow for one extra year before starting to assess the impact of the policy. Contrary to loans, the effect on interest rates is increasing over time, as it ranges from 45 base points over two years to 53 base points over three years. IVE estimates are somewhat bigger than OLS in absolute value.

- Probability of default (table 6): we assess the policy's impact on the probability of default by estimating a linear probability model. OLS estimates do not show any significant effect on the probability of loans turning 'bad'; when we estimate our model through IVE, the coefficient becomes marginally significant over the first two years. Trade debts (table 7): OLS results suggest that the public guarantee did not lead to a reduction in trade debts; this is confirmed by IVE.

- Investments (table 8): The OLS estimates indicate a positive effect of the policy on firm investments, which is significant in the first year only, suggesting intertemporal substitution (Bronzini and de Blasio, 2006). When we estimate our model through IVE, the coefficient is larger and still significant for the first year; when we consider longer post intervention periods we find no significant effect: 8

\footnotetext{
${ }^{8}$ This result might also be affected by the optional revaluation of fixed assets undertaken by firms, according to decree law no. 185 of 29 november 2008 .
} 
It is worth stressing, however, that the absence of effects on real outcomes should not be interpreted as conclusive: first, balance-sheet data are notably less precise and reliable than other sources; second, the time horizon considered (three years) might be too short, as the additional funding may produce positive effects with a longer time lag, especially for turnover 9 Third, the policy coincided with the the outbreak of the international financial crisis, which resulted in a deep contraction of economic activity in Italy. This in turn implied a general levelling-off of investments and turnover which helped reduce differences between treated and control firms.

\subsection{Heterogeneous effects}

Although the results are quite clear-cut, it could still be possible that the policy outcome is substantially different for a specific subgroup of firms. We investigate this possibility along two different dimensions: firm age and firm size (as measured by yearly turnover). The traditional approach for testing for heterogeneous effects is by means of a sample split at the median. The results (available upon request) do not show any statistically significant heterogeneous effect. However, the lack of significance could also be due to a lower precision of IV estimates with smaller samples. With the available data, we cannot therefore be conclusive as to the existence of heterogeneous effects.

\section{$7 \quad$ Difference in differences method}

In this section we provide some robustness and assess the impact of the policy by means of a matching - difference in differences method. The treatment group consists of all firms which first benefited from the guarantee in 2008 from "bank A". We exploit the fact that $70 \%$ of those firms were previously borrowing from "bank A" to restrict our focus to this subset (95 firms), matching it with a similar set of "untreated" firms that were also borrowing from "bank A" before 2008. We perform a nearest neighbour matching, exploiting firms' location, sector, pre-treatment dynamics of both long-term debt and total debt, pre-treatment amount of borrowed funds (both longterm and short term). In particular, we associate each "treated" firm to three very similar "untreated" firms, ending up with a sample of 380 firms, described in table 11.

We then estimate the following model:

$$
y_{i t}=\beta_{0}+\beta_{1} d s u b s i d y+\beta_{2} \text { post }_{t}+\delta d s u b s i d y \cdot \text { post }_{t}+\epsilon_{i, t}
$$

\footnotetext{
${ }^{9}$ We would, instead, expect a short-term effect of improved financial conditions on investments and trade debt.
} 
where $y_{i}$ is our outcome variable, "dsubsidy" is a dummy indicating whether or not the firm received the guarantee, and "post" is a dummy equal to 1 from 2008 onwards.

The estimates of the DID model (table 12 are in line with our previous findings. On average, the estimates show that there is no impact on total bank debt, while firms increase the amount of long-term debt, suggesting that, in the absence of treatment, firms over-rely on short term credit. We also find that treated firms face a statistically significant reduction of the cost of debt, with an estimated drop of 24 base points. On the other hand, in accordance with previous results, there seem to be no effects on real outcomes.

\section{Falsification test}

We design two different falsification tests to reinforce the validity of our identification strategy. The first test simulates the policy in a region adjacent to the one under analysis. We then create a placebo treatment based on the same criteria we used to build our instrumental variable. We create a treatment dummy which is equal to one in year 2008 if firms were funded by the covenant bank B in 2005 and they were eligible in 2007. In all other respects, the regressions are identical to those reported earlier. If this placebo treatment ended up being significant, it would mean that the way in which we build our instrumental variables introduces a bias. If, on the contrary, the placebo treatment proved insignificant, this would provide supporting evidence for our exclusion restrictions. T results (see table 9 show that this is indeed the case: the placebo treatment is never significant, and point estimates are generally close to zero.

The second falsification exercise aims at testing the validity of the exclusion restrictions of the 2SLS estimation. The test consists in regressing (by OLS) the output variables on the instrumental variables and other controls, while limiting the sample to the group of untreated eligible firms. The intuition here is that, under standard exclusion restrictions, the instrument should not have any direct effect on the output variables; the only effect of the instrument on the dependent variable is indirect, and passes through the treatment. We therefore estimate the model of equation 1 only on the group of untreated eligible firms. Again, the results (table 10 support the validity of the exclusion restrictions, since the instrument is never significant across all regressions. 


\section{Limits: extensive margin, LATE, and external validity}

The recent econometric literature has pointed out that in some circumstances IV estimates may be consistent only for some groups of observation, leading to the estimation of a local average treatment effect (LATE), rather than the average across the full sample (ATE). Furthermore, the validity of the IV estimation relies on the so-called monotonicity assumption on the functional form of the first stage equation (Imbens and Angrist, 1994). In our setting, the treatment of LATE should be generalized to the case in which covariates are included in the regression, and exclusion restrictions are more plausible after conditioning on covariates. Under conventional LATE assumptions, 2SLS would produce a weighted average of covariate-specific LATEs, which are less intuitive to treat than traditional LATE in univariate 2SLS, but are also (more) likely to approximate the real causal relationship of interest (Angrist and Pischke, 2008). This seems to be confirmed by the fact that our 2SLS results are reassuringly similar to those obtained via a simpler DID estimator. This leads us to conclude that our estimates should not be very far from the real ATE.

Another limit to the generality of our findings is their external validity, due to the geographically limited scope of the program. More generally, external validity is often an issue in studies which mainly focus on the identification strategy (e.g., contributions in experimental economics involving one or a few villages in a developing country). Since the program targets firms located in just one region (although as populous as a small European country), the sample of firms involved can be quite specific, and their response to treatment may be influenced by some local idiosyncratic firm characteristics, being therefore different from the potential response of firms in other regions or countries. However, by including non-treated firms located in neighbouring regions, we are able to control for some observed and unobserved regional effects. The extraordinary circumstances of the period under analysis, coincident with the 2008 international financial crisis and the related credit crunch, also need to be taken into account: it could be that in more normal times the policy would produce different effects. On the other hand, as we mentioned earlier, the unforeseen worsening of credit conditions for SMEs provides interesting exogenous variation in our setting, since we can assume that almost all eligible firms were financially constrained when the policy was implemented. Furthermore, unfortunately for Italy and Europe, neither the crisis nor the credit crunch appear to be over.

Finally, it is worth mentioning that our results consider the intensive margin only. To avoid a selection bias originating from firms entering or exiting the sample for unknown (but perhaps non-random) reasons, we limit the analysis to firms which we could track continuously for both the balance 
sheet and credit data from 2005 to 2010 . Therefore, firms with a total bank debt volume of less than $€ 75,000$ before 2005 which eventually increased their debt volume thanks to the policy are excluded. However, the policy itself was implicitly targeting incumbent firms, by requiring a turnover of more than $€ 1$ million in 2007 - a value very difficult to achieve without having accessed banking finance previously. Our data show that 95 per cent of the firms targeted by the policy were borrowing money from banks in 2005.

\section{Conclusion}

Guarantee schemes are widespread in both developed and developing economies, where they are seen as an effective instrument for improving the access to financial assets for entrepreneurial activities, especially SMEs. They are often funded by public institutions, and their implementation is frequently listed among the policy recommendations of international organizations. The popularity of guarantee schemes is due to the multiplicative effects embedded in these policies, their capacity to move private capital, and the possibility of recovering a large share of the public fund at the end of the program.

Despite their prevalence, economic theory is not conclusive on the net effect of CGSs on firms finance. In this paper we evaluate the effectiveness of a partial credit guarantee policy program, using unique micro-data from a large set of Italian firms. Using instrumental variable estimations based on specific features of the program, we are able to identify the treatment effect of the policy on a number of potential outcome variables - such as the total bank debt of each firm, the cost of credit, the debt structure, the firm turnover, and the probability of default - in the two-three years following treatment.

We find that the program had no significant impact on the total volume of firms' bank debt. On the other hand, the policy led to a statistically significant increase in the volume of long term debt. This is an interesting outcome, since international comparisons suggest that Italian SMEs have a debt structure unbalanced toward the short-term component (Brandolini and Bugamelli, 2009; Fagiolo and Luzzi, 2006). The introduction of the policy also resulted in lower interest rates being paid by beneficiary firms. There is, however, some evidence of moral hazard by firms, with the probability of default being marginally significant. Firm investments showed a weakly significant increase in the first year only. The lack of "real" effects, however, might be partly due to data limitation and the short temporal horizon.

IV results are confirmed by those obtained through an alternative identification strategy, involving a difference in differences estimation over a sample of homogeneous firms. Moreover, the results survive a battery of highly demanding falsification tests. 


\section{References}

Angrist, J. and Pischke, J. (2008). Mostly Harmless Econometrics: An Empiricist's Companion, Princeton University Press, Princeton, NJ.

Bank of Italy (2011). Geographical breakdown of credit supply and demand in 2010, Regional Economies .

Barone, G., Felici, R. and Pagnini, M. (2011). Switching costs in local credit markets, International Journal of Industrial Organization 29(6): 694704 .

Beck, T., Klapper, L. and Mendoza, J. (2008). The typology of partial credit guarantee funds around the world, The World Bank, Policy research working paper $n$. 4771 .

Benavente, J. M., Galetovic, A. and Sanhueza, R. (2006). Fogape: an economic analysis, mimeo .

Brandolini, A. and Bugamelli, M. (eds) (2009). Reports on trends in the Italian productive system, Occasional paper 45-09, Bank of Italy.

Bronzini, R. and de Blasio, G. (2006). Evaluating the impact of investment incentives: The case of Italy's law 488/92, Journal of Urban Economics 60: $327-349$.

Columba, F., Gambacorta, L. and Mistrulli, P. (2009). Mutual guarantee institutions and small business finance, Discussion paper 735-09, Bank of Italy .

de Meza, D. (2002). Overlending?, The Economic Journal 112.

European Commission (2011a). Press release, http://europa.eu .

European Commission (2011b). SMEs' access to finance, Survey 2011.

Fagiolo, G. and Luzzi, A. (2006). Do liquidity constraints matter in explaining firm size and growth? Some evidence from the Italian manufacturing industry, Industrial and Corporate Change, 2006.

Hancock, D., Peek, J. and Wilcox, J. (2007). The repercussions on small banks and small business of bank capital and loan guarantees, Working paper 07-22, Wharton University .

Imbens, G. W. and Angrist, J. D. (1994). Identification and estimation of local average treatment effects, Econometrica 62 (2): 467-475.

Kang, J. W. and Heshmati, A. (2008). Effect of credit guarantee policy on survival and performance of SMEs in Republic of Korea, Small Business Economics 31. 
Lelarge, C., Sraer, D. and Thesmar, D. (2008). Entrepreneurship and credit constraints. evidence from a French loan guarantee program, mimeo .

Meyer, R. L. and Nagarajan, G. (1996). Evaluating credit guarantee programs in developing countries, mimeo .

Mistrulli, P. and Vacca, V. (eds) (2011). Mutual guarantee institutions and small business credit during the crisis, Occasional paper 105, Bank of Italy.

OECD (2011). The impact of the global crisis on SME and entrepreneurship financing and policy responses, Contribution to the OECD Strategic Response to the Financial and Economic Crisis .

Riding, A., Madill, J. and Haines, G. (2007). Incrementality of SME loan guarantees, Small Business Economics 29.

Stock, J. and Yogo, M. (2005). Testing for Weak Instruments in Linear IV Regression, in D.W.K. Andrews and J.H. Stock (eds.), Identification and Inference for Econometric Models, Essays in Honor of Thomas Rothenberg, Cambridge University Press, New York, pp. 80-108.

Vogel, R. and Adams, D. (1997). Costs and benefits of loan guarantee programs, The Financier - Analyses of Capital and Money Market Transactions 4.

Wooldridge, J. (2002). Econometric Analysis of Cross Section and Panel Data, MIT Press, Cambridge, Mass.

Zecchini, S. and Ventura, M. (2009). The impact of public guarantees on credit to SMEs, Small Business Economics $\mathbf{3 2}$. 


\section{Tables}

Table 1: Sample descriptive statistics

\begin{tabular}{|c|c|c|c|c|c|c|c|c|c|}
\hline Stat. & \multicolumn{2}{|c|}{ Total debt } & g-term d & ebt & $\begin{array}{r}\text { Prob of } \\
\text { default }\end{array}$ & \multicolumn{2}{|c|}{$\begin{array}{c}\text { Interest } \\
\text { rate }\end{array}$} & Riskiness & Sales \\
\hline \multicolumn{10}{|c|}{ Untreated } \\
\hline mean & \multicolumn{2}{|l|}{3005270} & \multicolumn{2}{|l|}{1856670} & 0.0 & \multicolumn{2}{|c|}{4.5} & 5.2 & 6972.3 \\
\hline median & \multicolumn{2}{|l|}{1336384} & \multicolumn{2}{|l|}{725456} & 0.0 & \multicolumn{2}{|c|}{4.6} & 5.0 & 3429.5 \\
\hline sd & \multicolumn{2}{|c|}{5188754} & 4020140 & & 0.1 & \multicolumn{2}{|c|}{1.4} & 1.8 & 9035.4 \\
\hline $\mathrm{n}$ & \multicolumn{2}{|l|}{6071} & 6071 & & 6071 & \multicolumn{2}{|c|}{5220} & 6060 & 6071 \\
\hline \multicolumn{10}{|c|}{ Treated } \\
\hline mean & \multicolumn{2}{|l|}{4705120} & \multicolumn{2}{|l|}{2378448} & 0.0 & \multicolumn{2}{|c|}{4.6} & 5.5 & 11950.4 \\
\hline median & \multicolumn{2}{|c|}{3377808} & \multicolumn{2}{|l|}{1333069} & 0.0 & \multicolumn{2}{|c|}{4.8} & 6.0 & 9014.5 \\
\hline sd & \multicolumn{2}{|l|}{4294053} & \multicolumn{2}{|l|}{2730099} & 0.1 & \multicolumn{2}{|c|}{1.4} & 1.4 & 10106.7 \\
\hline $\mathrm{n}$ & \multicolumn{2}{|l|}{152} & 152 & & 152 & & & 152 & 152 \\
\hline Stat. & $\begin{array}{l}\text { Total } \\
\text { assets }\end{array}$ & $\begin{array}{l}\text { Tang. } \\
\text { assets }\end{array}$ & $\begin{array}{r}\text { Trade } \\
\text { debt }\end{array}$ & Ley & jerage & $\begin{array}{r}\text { No. of } \\
\text { banks }\end{array}$ & $\begin{array}{r}\text { Yea } \\
\text { es }\end{array}$ & & \\
\hline & & & Untreat & ed & & & & & \\
\hline mean & 7605.4 & 2096.2 & 1695.9 & & 0.7 & 5.0 & & & \\
\hline median & 3706.0 & 580.0 & 730.0 & & 0.7 & 4.0 & & & \\
\hline sd & 12332.5 & 6066.1 & 2704.4 & & 1.7 & 3.4 & & & \\
\hline $\mathrm{n}$ & 6071 & 6071 & 6071 & & 071 & 6071 & & & \\
\hline & & & Treate & & & & & & \\
\hline mean & 11373.3 & 2151.6 & 3298.8 & & 0.7 & 6.7 & & & \\
\hline median & 8231.0 & 887.0 & 2395.0 & & 0.8 & 6.0 & & & \\
\hline sd & 9573.9 & 3221.4 & 3123.4 & & 0.2 & 3.9 & & & \\
\hline $\mathrm{n}$ & 152 & 152 & 152 & & 152 & 152 & & & \\
\hline
\end{tabular}


Table 2: Long-term bank debt

\begin{tabular}{|c|c|c|c|c|c|c|}
\hline \multirow[b]{2}{*}{ Dep. variable } & OLS & IV & OLS & IV & OLS & IV \\
\hline & \multicolumn{6}{|c|}{ Long-term bank debt } \\
\hline Treated 1 year & $\begin{array}{c}0.363^{* * *} \\
(0.052)\end{array}$ & $\begin{array}{c}0.403^{* *} \\
(0.158)\end{array}$ & & & & \\
\hline Treated 2 years & & & $\begin{array}{c}0.328^{* * *} \\
(0.053)\end{array}$ & $\begin{array}{l}0.229 * \\
(0.130)\end{array}$ & & \\
\hline Treated 3 years & & & & & $\begin{array}{c}0.295^{* * *} \\
(0.056)\end{array}$ & $\begin{array}{c}0.212 \\
(0.131)\end{array}$ \\
\hline Turnover (t-1) & $\begin{array}{c}0.022 \\
(0.038)\end{array}$ & $\begin{array}{c}0.022 \\
(0.038)\end{array}$ & $\begin{array}{c}0.080^{* * *} \\
(0.030)\end{array}$ & $\begin{array}{c}0.080^{* * *} \\
(0.028)\end{array}$ & $\begin{array}{c}0.072^{* * *} \\
(0.024)\end{array}$ & $\begin{array}{c}0.072^{* * *} \\
(0.021)\end{array}$ \\
\hline Total assets $(\mathrm{t}-1)$ & $\begin{array}{c}0.378^{* * *} \\
(0.047)\end{array}$ & $\begin{array}{c}0.378^{* * *} \\
(0.048)\end{array}$ & $\begin{array}{c}0.359^{* * *} \\
(0.030)\end{array}$ & $\begin{array}{c}0.360^{* * *} \\
(0.029)\end{array}$ & $\begin{array}{c}0.423^{* * *} \\
(0.028)\end{array}$ & $\begin{array}{c}0.423^{* * *} \\
(0.024)\end{array}$ \\
\hline Low riskiness $(\mathrm{t}-1)$ & $\begin{array}{c}0.021 \\
(0.036)\end{array}$ & $\begin{array}{c}0.021 \\
(0.035)\end{array}$ & $\begin{array}{c}-0.075^{* *} \\
(0.030)\end{array}$ & $\begin{array}{c}-0.076^{* * *} \\
(0.027)\end{array}$ & $\begin{array}{c}-0.082^{* * *} \\
(0.026)\end{array}$ & $\begin{array}{c}-0.083^{* * *} \\
(0.023)\end{array}$ \\
\hline Medium riskiness (t-1) & $\begin{array}{l}-0.018 \\
(0.018)\end{array}$ & $\begin{array}{l}-0.018 \\
(0.017)\end{array}$ & $\begin{array}{c}-0.039^{* * *} \\
(0.014)\end{array}$ & $\begin{array}{c}-0.039^{* * *} \\
(0.014)\end{array}$ & $\begin{array}{c}-0.041^{* * *} \\
(0.013)\end{array}$ & $\begin{array}{c}-0.042^{* * *} \\
(0.012)\end{array}$ \\
\hline No. of banks (t-1) & $\begin{array}{c}0.088^{* * *} \\
(0.025)\end{array}$ & $\begin{array}{c}0.088^{* * *} \\
(0.025)\end{array}$ & $\begin{array}{c}0.143^{* * *} \\
(0.022)\end{array}$ & $\begin{array}{c}0.143^{* * *} \\
(0.020)\end{array}$ & $\begin{array}{c}0.162^{* * *} \\
(0.019)\end{array}$ & $\begin{array}{c}0.162^{* * *} \\
(0.018)\end{array}$ \\
\hline Firm age & $\begin{array}{c}0.115 \\
(0.182)\end{array}$ & $\begin{array}{c}0.114 \\
(0.171)\end{array}$ & $\begin{array}{c}0.211 \\
(0.163)\end{array}$ & $\begin{array}{c}0.212 \\
(0.152)\end{array}$ & $\begin{array}{c}0.411^{* *} \\
(0.190)\end{array}$ & $\begin{array}{c}0.413^{* *} \\
(0.176)\end{array}$ \\
\hline Observations & 12633 & 12633 & 16805 & 16805 & 20923 & 20923 \\
\hline R-square (within) & 0.058 & 0.034 & 0.065 & 0.046 & 0.078 & 0.060 \\
\hline Number of firms & 4280 & 4280 & 4280 & 4280 & 4280 & 4280 \\
\hline F-stat excl. instr. & & 94.12 & & 207.2 & & 234.9 \\
\hline
\end{tabular}

Robust standard errors in parentheses.

${ }^{* * *} \mathrm{p}<0.01,{ }^{* *} \mathrm{p}<0.05,{ }^{*} \mathrm{p}<0.1$.

All regressions include Region*Year and Bank*Year fixed effects. 
Table 3: Total bank debt

\begin{tabular}{|c|c|c|c|c|c|c|}
\hline & OLS & IV & OLS & IV & OLS & IV \\
\hline Dep. variable & \multicolumn{6}{|c|}{ Total bank debt } \\
\hline Treated 1 year & $\begin{array}{c}0.166^{* * *} \\
(0.034)\end{array}$ & $\begin{array}{l}-0.048 \\
(0.108)\end{array}$ & & & & \\
\hline Treated 2 years & & & $\begin{array}{c}0.140^{* * *} \\
(0.036)\end{array}$ & $\begin{array}{l}-0.105 \\
(0.090)\end{array}$ & & \\
\hline Treated 3 years & & & & & $\begin{array}{c}0.122^{* * *} \\
(0.037)\end{array}$ & $\begin{array}{l}-0.126 \\
(0.088)\end{array}$ \\
\hline Turnover (t-1) & $\begin{array}{c}0.037 \\
(0.029)\end{array}$ & $\begin{array}{c}0.036 \\
(0.028)\end{array}$ & $\begin{array}{c}0.101^{* * *} \\
(0.025)\end{array}$ & $\begin{array}{c}0.101^{* * *} \\
(0.022)\end{array}$ & $\begin{array}{c}0.124^{* * *} \\
(0.020)\end{array}$ & $\begin{array}{c}0.123^{* * *} \\
(0.017)\end{array}$ \\
\hline Total assets (t-1) & $\begin{array}{c}0.296^{* * *} \\
(0.034)\end{array}$ & $\begin{array}{c}0.298^{* * *} \\
(0.034)\end{array}$ & $\begin{array}{c}0.291^{* * *} \\
(0.022)\end{array}$ & $\begin{array}{c}0.292^{* * *} \\
(0.021)\end{array}$ & $\begin{array}{c}0.353^{* * *} \\
(0.021)\end{array}$ & $\begin{array}{c}0.354^{* * *} \\
(0.018)\end{array}$ \\
\hline Low riskiness $(\mathrm{t}-1)$ & $\begin{array}{c}0.012 \\
(0.025)\end{array}$ & $\begin{array}{c}0.011 \\
(0.025)\end{array}$ & $\begin{array}{c}-0.088^{* * *} \\
(0.021)\end{array}$ & $\begin{array}{c}-0.091^{* * *} \\
(0.020)\end{array}$ & $\begin{array}{c}-0.115^{* * *} \\
(0.018)\end{array}$ & $\begin{array}{c}-0.118^{* * *} \\
(0.017)\end{array}$ \\
\hline Medium riskiness $(\mathrm{t}-1)$ & $\begin{array}{c}-0.022^{* *} \\
(0.011)\end{array}$ & $\begin{array}{c}-0.023^{* *} \\
(0.011)\end{array}$ & $\begin{array}{c}-0.047^{* * *} \\
(0.009)\end{array}$ & $\begin{array}{c}-0.047^{* * *} \\
(0.009)\end{array}$ & $\begin{array}{c}-0.054^{* * *} \\
(0.009)\end{array}$ & $\begin{array}{c}-0.055^{* * *} \\
(0.008)\end{array}$ \\
\hline No. of banks $(\mathrm{t}-1)$ & $\begin{array}{c}0.102^{* * *} \\
(0.020)\end{array}$ & $\begin{array}{c}0.103^{* * *} \\
(0.019)\end{array}$ & $\begin{array}{c}0.154^{* * *} \\
(0.017)\end{array}$ & $\begin{array}{c}0.155^{* * *} \\
(0.016)\end{array}$ & $\begin{array}{c}0.179^{* * *} \\
(0.015)\end{array}$ & $\begin{array}{c}0.180^{* * *} \\
(0.014)\end{array}$ \\
\hline Firm age & $\begin{array}{c}-0.042 \\
(0.091)\end{array}$ & $\begin{array}{c}-0.037 \\
(0.090)\end{array}$ & $\begin{array}{c}0.057 \\
(0.084)\end{array}$ & $\begin{array}{c}0.060 \\
(0.084)\end{array}$ & $\begin{array}{l}0.124^{*} \\
(0.065)\end{array}$ & $\begin{array}{c}0.130 * * \\
(0.060)\end{array}$ \\
\hline Observations & 12633 & 12633 & 16805 & 16805 & 20923 & 20923 \\
\hline R-square (within) & 0.120 & 0.039 & 0.132 & 0.066 & 0.156 & 0.097 \\
\hline Number of firms & 4280 & 4280 & 4280 & 4280 & 4280 & 4280 \\
\hline F-stat excl. instr. & & 94.12 & & 207.2 & & 234.9 \\
\hline
\end{tabular}

Robust standard errors in parentheses.

*** $\mathrm{p}<0.01,{ }^{* *} \mathrm{p}<0.05,{ }^{*} \mathrm{p}<0.1$.

All regressions include Region*Year and Bank*Year fixed effects. 
Table 4: Share of long-term bank debt over total bank debt

\begin{tabular}{|c|c|c|c|c|c|c|}
\hline \multirow[b]{2}{*}{ Dep. variable } & OLS & IV & OLS & IV & OLS & IV \\
\hline & \multicolumn{6}{|c|}{ Share of long-term bank debt over total bank debt } \\
\hline Treated 1 year & $\begin{array}{c}0.198^{* * *} \\
(0.040)\end{array}$ & $\begin{array}{c}0.451^{* * *} \\
(0.139)\end{array}$ & & & & \\
\hline Treated 2 years & & & $\begin{array}{c}0.188^{* * *} \\
(0.040)\end{array}$ & $\begin{array}{c}0.334^{* * *} \\
(0.108)\end{array}$ & & \\
\hline Treated 3 years & & & & & $\begin{array}{c}0.174^{* * *} \\
(0.042)\end{array}$ & $\begin{array}{c}0.338^{* * *} \\
(0.105)\end{array}$ \\
\hline Turnover (t-1) & $\begin{array}{l}-0.014 \\
(0.025)\end{array}$ & $\begin{array}{l}-0.014 \\
(0.025)\end{array}$ & $\begin{array}{c}-0.021 \\
(0.020)\end{array}$ & $\begin{array}{l}-0.021 \\
(0.018)\end{array}$ & $\begin{array}{c}-0.051^{* * *} \\
(0.017)\end{array}$ & $\begin{array}{c}-0.051^{* * *} \\
(0.015)\end{array}$ \\
\hline Total assets $(\mathrm{t}-1)$ & $\begin{array}{c}0.082^{* * *} \\
(0.025)\end{array}$ & $\begin{array}{c}0.080^{* * *} \\
(0.026)\end{array}$ & $\begin{array}{c}0.069^{* * *} \\
(0.017)\end{array}$ & $\begin{array}{c}0.068^{* * *} \\
(0.017)\end{array}$ & $\begin{array}{c}0.070^{* * *} \\
(0.016)\end{array}$ & $\begin{array}{c}0.069 * * * \\
(0.014)\end{array}$ \\
\hline Low riskiness $(\mathrm{t}-1)$ & $\begin{array}{c}0.009 \\
(0.024)\end{array}$ & $\begin{array}{c}0.009 \\
(0.023)\end{array}$ & $\begin{array}{c}0.013 \\
(0.019)\end{array}$ & $\begin{array}{c}0.014 \\
(0.018)\end{array}$ & $\begin{array}{c}0.033^{*} \\
(0.017)\end{array}$ & $\begin{array}{c}0.035 * * \\
(0.016)\end{array}$ \\
\hline Medium riskiness $(\mathrm{t}-1)$ & $\begin{array}{c}0.004 \\
(0.013)\end{array}$ & $\begin{array}{c}0.005 \\
(0.012)\end{array}$ & $\begin{array}{c}0.008 \\
(0.010)\end{array}$ & $\begin{array}{c}0.008 \\
(0.010)\end{array}$ & $\begin{array}{c}0.013 \\
(0.009)\end{array}$ & $\begin{array}{c}0.014 \\
(0.009)\end{array}$ \\
\hline No. of banks $(\mathrm{t}-1)$ & $\begin{array}{l}-0.014 \\
(0.017)\end{array}$ & $\begin{array}{l}-0.015 \\
(0.017)\end{array}$ & $\begin{array}{c}-0.011 \\
(0.014)\end{array}$ & $\begin{array}{l}-0.012 \\
(0.013)\end{array}$ & $\begin{array}{l}-0.018 \\
(0.012)\end{array}$ & $\begin{array}{l}-0.018 \\
(0.011)\end{array}$ \\
\hline Firm age & $\begin{array}{c}0.157 \\
(0.113)\end{array}$ & $\begin{array}{c}0.152 \\
(0.109)\end{array}$ & $\begin{array}{c}0.154 \\
(0.104)\end{array}$ & $\begin{array}{c}0.152 \\
(0.102)\end{array}$ & $\begin{array}{c}0.287^{*} \\
(0.153)\end{array}$ & $\begin{array}{c}0.283^{* *} \\
(0.143)\end{array}$ \\
\hline Observations & 12633 & 12633 & 16805 & 16805 & 20923 & 20923 \\
\hline R-square (within) & 0.029 & -0.001 & 0.025 & 0.003 & 0.025 & 0.003 \\
\hline Number of firms & 4280 & 4280 & 4280 & 4280 & 4280 & 4280 \\
\hline F-stat excl. instr. & & 94.12 & & 207.2 & & 234.9 \\
\hline
\end{tabular}

Robust standard errors in parentheses.

*** $\mathrm{p}<0.01,{ }^{* *} \mathrm{p}<0.05,{ }^{*} \mathrm{p}<0.1$.

All regressions include Region*Year and Bank*Year fixed effects. 
Table 5: Interest rate

\begin{tabular}{|c|c|c|c|c|}
\hline & OLS & IV & OLS & IV \\
\hline Dep. variable & \multicolumn{4}{|c|}{ Interest rate } \\
\hline Treated 2 years & $\begin{array}{c}-0.453^{* * *} \\
(0.077)\end{array}$ & $\begin{array}{c}-0.866^{* *} \\
(0.350)\end{array}$ & & \\
\hline Treated 3 years & & & $\begin{array}{c}-0.526^{* * *} \\
(0.081)\end{array}$ & $\begin{array}{c}-1.264^{* * *} \\
(0.349)\end{array}$ \\
\hline Turnover $(\mathrm{t}-1)$ & $\begin{array}{c}-0.107^{*} \\
(0.060)\end{array}$ & $\begin{array}{l}-0.108^{*} \\
(0.059)\end{array}$ & $\begin{array}{c}-0.049 \\
(0.055)\end{array}$ & $\begin{array}{l}-0.050 \\
(0.046)\end{array}$ \\
\hline Total assets (t-1) & $\begin{array}{c}-0.096 \\
(0.067)\end{array}$ & $\begin{array}{l}-0.092 \\
(0.064)\end{array}$ & $\begin{array}{c}-0.157^{* *} \\
(0.067)\end{array}$ & $\begin{array}{c}-0.151^{* * *} \\
(0.048)\end{array}$ \\
\hline Low riskiness $(\mathrm{t}-1)$ & $\begin{array}{c}-0.131^{* *} \\
(0.064)\end{array}$ & $\begin{array}{c}-0.135^{* *} \\
(0.061)\end{array}$ & $\begin{array}{c}-0.205^{* * *} \\
(0.060)\end{array}$ & $\begin{array}{c}-0.214^{* * *} \\
(0.053)\end{array}$ \\
\hline Medium riskiness $(\mathrm{t}-1)$ & $\begin{array}{c}-0.076^{* *} \\
(0.031)\end{array}$ & $\begin{array}{c}-0.078^{* * *} \\
(0.030)\end{array}$ & $\begin{array}{c}-0.120^{* * *} \\
(0.030)\end{array}$ & $\begin{array}{c}-0.125^{* * *} \\
(0.027)\end{array}$ \\
\hline No. of banks (t-1) & $\begin{array}{c}-0.043 \\
(0.045)\end{array}$ & $\begin{array}{c}-0.044 \\
(0.046)\end{array}$ & $\begin{array}{c}-0.081^{*} \\
(0.043)\end{array}$ & $\begin{array}{c}-0.081^{* *} \\
(0.039)\end{array}$ \\
\hline Firm age & $\begin{array}{c}0.072 \\
(0.109)\end{array}$ & $\begin{array}{c}0.078 \\
(0.206)\end{array}$ & $\begin{array}{c}0.161 \\
(0.128)\end{array}$ & $\begin{array}{c}0.169 \\
(0.180)\end{array}$ \\
\hline Observations & 7215 & 7215 & 8793 & 8793 \\
\hline R-square (within) & 0.733 & 0.005 & 0.742 & 0.004 \\
\hline Number of firms & 2125 & 2125 & 2125 & 2125 \\
\hline F-stat excl. instr. & & 65.61 & & 73.27 \\
\hline
\end{tabular}

Robust standard errors in parentheses.

$* * * \mathrm{p}<0.01,{ }^{* *} \mathrm{p}<0.05,{ }^{*} \mathrm{p}<0.1$.

All regressions include Region*Year and Bank*Year fixed effects. 
Table 6: Probability of default

\begin{tabular}{|c|c|c|c|c|c|c|}
\hline \multirow[b]{2}{*}{ Dep. variable } & OLS & IV & OLS & IV & OLS & IV \\
\hline & \multicolumn{6}{|c|}{ Probability of default } \\
\hline Treated 1 year & $\begin{array}{c}0.009 \\
(0.008)\end{array}$ & $\begin{array}{l}0.025^{*} \\
(0.015)\end{array}$ & & & & \\
\hline Treated 2 years & & & $\begin{array}{c}0.008 \\
(0.006)\end{array}$ & $\begin{array}{l}0.025^{*} \\
(0.014)\end{array}$ & & \\
\hline Treated 3 years & & & & & $\begin{array}{c}0.006 \\
(0.006)\end{array}$ & $\begin{array}{c}0.022 \\
(0.014)\end{array}$ \\
\hline Turnover (t-1) & $\begin{array}{l}-0.003 \\
(0.003)\end{array}$ & $\begin{array}{l}-0.003 \\
(0.003)\end{array}$ & $\begin{array}{l}-0.003 \\
(0.002)\end{array}$ & $\begin{array}{l}-0.003 \\
(0.002)\end{array}$ & $\begin{array}{c}-0.012^{* * *} \\
(0.004)\end{array}$ & $\begin{array}{c}-0.012^{* * *} \\
(0.004)\end{array}$ \\
\hline Total assets $(\mathrm{t}-1)$ & $\begin{array}{c}0.000 \\
(0.003)\end{array}$ & $\begin{array}{c}0.000 \\
(0.003)\end{array}$ & $\begin{array}{l}-0.000 \\
(0.002)\end{array}$ & $\begin{array}{l}-0.000 \\
(0.002)\end{array}$ & $\begin{array}{l}-0.002 \\
(0.003)\end{array}$ & $\begin{array}{l}-0.002 \\
(0.003)\end{array}$ \\
\hline Low riskiness $(\mathrm{t}-1)$ & $\begin{array}{l}-0.001 \\
(0.002)\end{array}$ & $\begin{array}{l}-0.001 \\
(0.002)\end{array}$ & $\begin{array}{c}-0.004^{* *} \\
(0.002)\end{array}$ & $\begin{array}{c}-0.004^{* *} \\
(0.002)\end{array}$ & $\begin{array}{c}-0.010^{* * *} \\
(0.002)\end{array}$ & $\begin{array}{c}-0.010^{* * *} \\
(0.002)\end{array}$ \\
\hline Medium riskiness ( $\mathrm{t}-1)$ & $\begin{array}{l}-0.000 \\
(0.002)\end{array}$ & $\begin{array}{l}-0.000 \\
(0.002)\end{array}$ & $\begin{array}{c}-0.004^{* *} \\
(0.002)\end{array}$ & $\begin{array}{c}-0.004^{* *} \\
(0.002)\end{array}$ & $\begin{array}{c}-0.009 * * * \\
(0.002)\end{array}$ & $\begin{array}{c}-0.008^{* * *} \\
(0.002)\end{array}$ \\
\hline No. of banks (t-1) & $\begin{array}{l}-0.002 \\
(0.002)\end{array}$ & $\begin{array}{l}-0.002 \\
(0.002)\end{array}$ & $\begin{array}{l}-0.002 \\
(0.001)\end{array}$ & $\begin{array}{l}-0.002 \\
(0.002)\end{array}$ & $\begin{array}{c}-0.005^{* *} \\
(0.002)\end{array}$ & $\begin{array}{c}-0.005^{* *} \\
(0.002)\end{array}$ \\
\hline Firm age & $\begin{array}{l}-0.033 \\
(0.036)\end{array}$ & $\begin{array}{l}-0.034 \\
(0.042)\end{array}$ & $\begin{array}{l}-0.020 \\
(0.022)\end{array}$ & $\begin{array}{c}-0.020 \\
(0.027)\end{array}$ & $\begin{array}{l}-0.015 \\
(0.016)\end{array}$ & $\begin{array}{l}-0.015 \\
(0.017)\end{array}$ \\
\hline Observations & 12633 & 12633 & 16805 & 16805 & 20923 & 20923 \\
\hline R-square (within) & 0.005 & -0.000 & 0.006 & 0.000 & 0.019 & 0.005 \\
\hline Number of firms & 4280 & 4280 & 4280 & 4280 & 4280 & 4280 \\
\hline F-stat excl. instr. & & 94.12 & & 207.2 & & 234.9 \\
\hline
\end{tabular}

Robust standard errors in parentheses.

${ }^{* * *} \mathrm{p}<0.01,{ }^{* *} \mathrm{p}<0.05,{ }^{*} \mathrm{p}<0.1$.

All regressions include Region*Year and Bank*Year fixed effects. 
Table 7: Trade debts

\begin{tabular}{|c|c|c|c|c|c|c|}
\hline & OLS & IV & OLS & IV & OLS & IV \\
\hline Dep. variable & \multicolumn{6}{|c|}{ Trade debts } \\
\hline Treated 1 year & $\begin{array}{c}0.040 \\
(0.047)\end{array}$ & $\begin{array}{c}0.049 \\
(0.119)\end{array}$ & & & & \\
\hline Treated 2 years & & & $\begin{array}{c}0.038 \\
(0.050)\end{array}$ & $\begin{array}{l}-0.040 \\
(0.115)\end{array}$ & & \\
\hline Treated 3 years & & & & & $\begin{array}{c}0.028 \\
(0.053)\end{array}$ & $\begin{array}{c}0.024 \\
(0.135)\end{array}$ \\
\hline Low riskiness $(\mathrm{t}-1)$ & $\begin{array}{l}-0.030 \\
(0.072)\end{array}$ & $\begin{array}{l}-0.030 \\
(0.085)\end{array}$ & $\begin{array}{c}0.011 \\
(0.063)\end{array}$ & $\begin{array}{c}0.011 \\
(0.078)\end{array}$ & $\begin{array}{c}0.179^{*} \\
(0.097)\end{array}$ & $\begin{array}{c}0.179^{*} \\
(0.100)\end{array}$ \\
\hline Medium riskiness $(\mathrm{t}-1)$ & $\begin{array}{c}0.001 \\
(0.025)\end{array}$ & $\begin{array}{c}0.001 \\
(0.025)\end{array}$ & $\begin{array}{c}-0.033 \\
(0.020)\end{array}$ & $\begin{array}{c}-0.034^{*} \\
(0.020)\end{array}$ & $\begin{array}{c}-0.108^{* * *} \\
(0.027)\end{array}$ & $\begin{array}{c}-0.108^{* * *} \\
(0.026)\end{array}$ \\
\hline No. of banks (t-1) & $\begin{array}{l}-0.016 \\
(0.014)\end{array}$ & $\begin{array}{l}-0.016 \\
(0.014)\end{array}$ & $\begin{array}{c}-0.013 \\
(0.012)\end{array}$ & $\begin{array}{l}-0.013 \\
(0.011)\end{array}$ & $\begin{array}{c}-0.008 \\
(0.013)\end{array}$ & $\begin{array}{c}-0.008 \\
(0.013)\end{array}$ \\
\hline Firm age & $\begin{array}{c}0.037^{*} \\
(0.020)\end{array}$ & $\begin{array}{c}0.037^{*} \\
(0.020)\end{array}$ & $\begin{array}{c}0.075^{* * *} \\
(0.017)\end{array}$ & $\begin{array}{c}0.075^{* * *} \\
(0.016)\end{array}$ & $\begin{array}{c}-0.005 \\
(0.021)\end{array}$ & $\begin{array}{l}-0.005 \\
(0.020)\end{array}$ \\
\hline Observations & 11280 & 11280 & 14886 & 14886 & 17948 & 17948 \\
\hline R-square (within) & 0.009 & 0.001 & 0.031 & 0.003 & 0.064 & 0.002 \\
\hline Number of firms & 3963 & 3963 & 3963 & 3963 & 3963 & 3963 \\
\hline F-stat excl. instr. & & 76.03 & & 152.6 & & 172.5 \\
\hline
\end{tabular}

Robust standard errors in parentheses.

*** $\mathrm{p}<0.01,{ }^{* *} \mathrm{p}<0.05,{ }^{*} \mathrm{p}<0.1$.

All regressions include Region*Year and Bank*Year fixed effects. 
Table 8: Investments

\begin{tabular}{|c|c|c|c|c|c|c|}
\hline & OLS & IV & OLS & IV & OLS & IV \\
\hline Dep. variable & \multicolumn{6}{|c|}{ Firm investments } \\
\hline Treated 1 year & $\begin{array}{c}0.081^{* *} \\
(0.036)\end{array}$ & $\begin{array}{c}0.220^{*} \\
(0.128)\end{array}$ & & & & \\
\hline Treated 2 years & & & $\begin{array}{c}0.034 \\
(0.027)\end{array}$ & $\begin{array}{c}0.121 \\
(0.093)\end{array}$ & & \\
\hline Treated 3 years & & & & & $\begin{array}{c}0.032 \\
(0.023)\end{array}$ & $\begin{array}{c}0.114 \\
(0.083)\end{array}$ \\
\hline Low riskiness $(\mathrm{t}-1)$ & $\begin{array}{c}0.038^{*} \\
(0.019)\end{array}$ & $\begin{array}{c}0.039 * * \\
(0.020)\end{array}$ & $\begin{array}{c}0.009 \\
(0.014)\end{array}$ & $\begin{array}{c}0.010 \\
(0.015)\end{array}$ & $\begin{array}{c}0.011 \\
(0.012)\end{array}$ & $\begin{array}{c}0.012 \\
(0.012)\end{array}$ \\
\hline Medium riskiness $(\mathrm{t}-1)$ & $\begin{array}{c}0.014 \\
(0.010)\end{array}$ & $\begin{array}{c}0.015 \\
(0.010)\end{array}$ & $\begin{array}{c}0.000 \\
(0.008)\end{array}$ & $\begin{array}{c}0.001 \\
(0.008)\end{array}$ & $\begin{array}{l}-0.000 \\
(0.006)\end{array}$ & $\begin{array}{c}0.000 \\
(0.006)\end{array}$ \\
\hline No. of banks $(\mathrm{t}-1)$ & $\begin{array}{l}-0.015 \\
(0.014)\end{array}$ & $\begin{array}{c}-0.016 \\
(0.014)\end{array}$ & $\begin{array}{c}-0.019 * * \\
(0.010)\end{array}$ & $\begin{array}{c}-0.020^{* *} \\
(0.010)\end{array}$ & $\begin{array}{c}-0.009 \\
(0.008)\end{array}$ & $\begin{array}{l}-0.010 \\
(0.008)\end{array}$ \\
\hline Firm age & $\begin{array}{c}0.067 \\
(0.066)\end{array}$ & $\begin{array}{c}0.063 \\
(0.076)\end{array}$ & $\begin{array}{c}0.020 \\
(0.061)\end{array}$ & $\begin{array}{c}0.018 \\
(0.068)\end{array}$ & $\begin{array}{c}-0.002 \\
(0.060)\end{array}$ & $\begin{array}{c}-0.005 \\
(0.058)\end{array}$ \\
\hline Observations & 11062 & 11062 & 14221 & 14221 & 17306 & 17306 \\
\hline R-square (within) & 0.060 & -0.001 & 0.082 & -0.001 & 0.076 & -0.001 \\
\hline Number of firms & 4139 & 4139 & 4139 & 4139 & 4139 & 4139 \\
\hline F-stat excl. instr. & & 46.46 & & 88.18 & & 97.16 \\
\hline
\end{tabular}

Robust standard errors in parentheses.

*** $\mathrm{p}<0.01,{ }^{* *} \mathrm{p}<0.05,{ }^{*} \mathrm{p}<0.1$.

All regressions include Region*Year and Bank*Year fixed effects. 
Table 9: Falsification test 1: other region

\begin{tabular}{lccccccc}
\hline Dep. variable & $\begin{array}{c}\text { Long-term } \\
\text { debt }\end{array}$ & $\begin{array}{c}\text { Total } \\
\text { debt }\end{array}$ & Share & $\begin{array}{c}\text { Interest } \\
\text { rate }\end{array}$ & $\begin{array}{c}\text { Prob of } \\
\text { default }\end{array}$ & $\begin{array}{c}\text { Invest- } \\
\text { ments }\end{array}$ & $\begin{array}{c}\text { Trade } \\
\text { debts }\end{array}$ \\
\hline Treated & 0.027 & -0.014 & 0.005 & -0.089 & & -0.036 & -0.016 \\
& $(0.041)$ & $(0.029)$ & $(0.021)$ & $(0.055)$ & & $(0.036)$ & $(0.035)$ \\
Observations & 6289 & 6289 & 6289 & 5085 & & 5571 & 5754 \\
R-square (within) & 0.044 & 0.110 & 0.045 & 0.751 & & 0.098 & 0.016 \\
\hline & & & & & & & \\
Treated 2 years & 0.046 & -0.013 & 0.005 & -0.079 & -0.000 & -0.030 & 0.008 \\
& $(0.041)$ & $(0.028)$ & $(0.019)$ & $(0.062)$ & $(0.004)$ & $(0.026)$ & $(0.035)$ \\
Observations & 8365 & 8365 & 8365 & 6597 & 8483 & 7135 & 7604 \\
R-square (within) & 0.057 & 0.126 & 0.040 & 0.807 & 0.017 & 0.126 & 0.055 \\
\hline & & & & & & & \\
Treated 3 years & 0.064 & -0.012 & 0.017 & -0.082 & 0.004 & -0.024 & -0.004 \\
& $(0.042)$ & $(0.029)$ & $(0.019)$ & $(0.066)$ & $(0.006)$ & $(0.023)$ & $(0.040)$ \\
& & & & & & & \\
Observations & 10421 & 10421 & 10421 & 8114 & 10597 & 8683 & 9222 \\
R-square (within) & 0.072 & 0.151 & 0.038 & 0.813 & 0.034 & 0.114 & 0.082 \\
\hline Robustandard errors in parentheses
\end{tabular}

Robust standard errors in parentheses.

$* * * \mathrm{p}<0.01, * * \mathrm{p}<0.05, * \mathrm{p}<0.1$.

All regressions include Region*Year and Bank* Year fixed effects.

All regressions include the corresponding set of controls reported in tables 2-7. 
Table 10: Falsification test 2: untreated eligible firms

\begin{tabular}{|c|c|c|c|c|c|c|c|}
\hline Dep. variable & $\begin{array}{c}\text { Long-term } \\
\text { debt }\end{array}$ & $\begin{array}{r}\text { Total } \\
\text { debt }\end{array}$ & Share & $\begin{array}{c}\text { Interest } \\
\text { rate }\end{array}$ & $\begin{array}{l}\text { Prob of } \\
\text { default }\end{array}$ & $\begin{array}{l}\text { Invest- } \\
\text { ments }\end{array}$ & $\begin{array}{l}\text { Trade } \\
\text { debts }\end{array}$ \\
\hline IV 1 year & $\begin{array}{c}0.091 \\
(0.207)\end{array}$ & $\begin{array}{l}-0.107 \\
(0.126)\end{array}$ & $\begin{array}{c}0.198 \\
(0.168)\end{array}$ & & $\begin{array}{c}0.017 \\
(0.014)\end{array}$ & $\begin{array}{c}0.070 \\
(0.129)\end{array}$ & $\begin{array}{c}0.036 \\
(0.164)\end{array}$ \\
\hline Observations & 12232 & 12232 & 12232 & & 12232 & 10714 & 10945 \\
\hline R-square (within) & 0.050 & 0.114 & 0.028 & & 0.005 & 0.059 & 0.010 \\
\hline IV 2 year & $\begin{array}{c}-0.109 \\
(0.213)\end{array}$ & $\begin{array}{c}-0.175 \\
(0.136)\end{array}$ & $\begin{array}{c}0.065 \\
(0.173)\end{array}$ & $\begin{array}{l}-0.230 \\
(0.340)\end{array}$ & $\begin{array}{c}0.015 \\
(0.011)\end{array}$ & $\begin{array}{c}0.015 \\
(0.083)\end{array}$ & $\begin{array}{l}-0.118 \\
(0.172)\end{array}$ \\
\hline $\begin{array}{l}\text { Observations } \\
\text { R-square (within) }\end{array}$ & $\begin{array}{l}16300 \\
0.060\end{array}$ & $\begin{array}{l}16300 \\
0.128\end{array}$ & $\begin{array}{l}16300 \\
0.024\end{array}$ & $\begin{array}{r}7293 \\
0.730\end{array}$ & $\begin{array}{l}16300 \\
0.006\end{array}$ & $\begin{array}{l}14449 \\
0.075\end{array}$ & $\begin{array}{l}14567 \\
0.031\end{array}$ \\
\hline IV 3 year & $\begin{array}{l}-0.060 \\
(0.222)\end{array}$ & $\begin{array}{l}-0.167 \\
(0.138)\end{array}$ & $\begin{array}{c}0.107 \\
(0.176)\end{array}$ & $\begin{array}{l}-0.408 \\
(0.406)\end{array}$ & $\begin{array}{c}0.011 \\
(0.014)\end{array}$ & $\begin{array}{c}0.044 \\
(0.071)\end{array}$ & $\begin{array}{l}-0.031 \\
(0.171)\end{array}$ \\
\hline Observations & 20328 & 20328 & 20328 & 9168 & 20328 & 18122 & 17692 \\
\hline R-square (within) & 0.075 & 0.155 & 0.025 & 0.736 & 0.019 & 0.069 & 0.064 \\
\hline
\end{tabular}

Robust standard errors in parentheses.

$* * * \mathrm{p}<0.01,{ }^{* *} \mathrm{p}<0.05,{ }^{*} \mathrm{p}<0.1$.

All regressions include Region*Year and Bank* Year fixed effects.

All regressions include the corresponding set of controls reported in tables 2-7. 
Table 11: DID sample

Obs.

Mean

Std. Dev. Min. Max.

Untreated

\begin{tabular}{lccccc} 
Long-term debt & 285 & 15.2 & 0.9 & 11.5 & 16.8 \\
Short-term debt & 285 & 14.4 & 1.1 & 11.0 & 16.5 \\
Interest rate & 239 & 6.0 & 0.5 & 4.0 & 6.9 \\
Turnover & 285 & 9.2 & 0.9 & 5.7 & 10.8 \\
\hline Capital & 285 & 6.6 & 1.6 & 0.0 & 10.0
\end{tabular}

Treated

\begin{tabular}{lccccc} 
Long-term debt & 95 & 15.2 & 0.9 & 11.9 & 16.6 \\
Short-term debt & 95 & 14.3 & 1.2 & 10.7 & 16.1 \\
Interest rate & 81 & 6.0 & 0.6 & 2.7 & 6.9 \\
\hline Turnover & 95 & 9.2 & 0.9 & 6.8 & 10.8 \\
Capital & 94 & 6.6 & 1.6 & 1.9 & 9.8
\end{tabular}

Note: all variables excluding interest rate are reported in logs. 
Table 12: matching-DID estimates

\begin{tabular}{|c|c|c|c|c|c|c|}
\hline Dep. variable & $\begin{array}{l}\text { (1) } \\
\text { Tot. debt }\end{array}$ & $\begin{array}{c}(2) \\
\text { Short t. debt }\end{array}$ & $\begin{array}{c}(3) \\
\text { Int. rate }\end{array}$ & $\begin{array}{c}(4) \\
\text { Prob of default }\end{array}$ & $\begin{array}{c}(5) \\
\text { Turnover }\end{array}$ & $\begin{array}{c}\text { (6) } \\
\text { Tot. assets }\end{array}$ \\
\hline Treated & $\begin{array}{c}0.072 \\
(0.104)\end{array}$ & $\begin{array}{l}-0.049 \\
(0.142)\end{array}$ & $\begin{array}{c}0.018 \\
(0.076)\end{array}$ & $\begin{array}{l}-0.001 \\
(0.003)\end{array}$ & $\begin{array}{c}0.124 \\
(0.105)\end{array}$ & $\begin{array}{l}-0.089 \\
(0.205)\end{array}$ \\
\hline Post & $\begin{array}{l}0.067^{* *} \\
(0.033)\end{array}$ & $\begin{array}{l}-0.039 \\
(0.055)\end{array}$ & $\begin{array}{c}-1.273^{* * *} \\
(0.079)\end{array}$ & $\begin{array}{l}0.010^{*} \\
(0.006)\end{array}$ & $\begin{array}{c}-0.054^{* *} \\
(0.024)\end{array}$ & $\begin{array}{c}0.314^{* * *} \\
(0.076)\end{array}$ \\
\hline Treated*post & $\begin{array}{c}0.080 \\
(0.057)\end{array}$ & $\begin{array}{l}0.291^{* * *} \\
(0.086)\end{array}$ & $\begin{array}{c}-0.240^{* *} \\
(0.111)\end{array}$ & $\begin{array}{c}0.012 \\
(0.012)\end{array}$ & $\begin{array}{c}0.006 \\
(0.045)\end{array}$ & $\begin{array}{c}0.154 \\
(0.113)\end{array}$ \\
\hline Observations & 1894 & 1894 & 1651 & 1894 & 1518 & 1511 \\
\hline$R^{2}$ & 0.123 & 0.114 & 0.215 & 0.038 & 0.200 & 0.198 \\
\hline
\end{tabular}

Robust standard errors in parenthese

*** $\mathrm{p}<0.01,{ }^{* *} \mathrm{p}<0.05,{ }^{*} \mathrm{p}<0.1$.

All regressions include Region*Year and Bank*Year fixed effects.

All regressions include the corresponding set of controls reported in tables 2-7. 


\section{BIS Department tor abinines Innovation \& Skills}

\section{Spatial Economics Research Centre (SERC)}

London School of Economics

Houghton Street

London WC2A 2AE

Tel: 02078523565

Fax: 02079556848

Web: www.spatialeconomics.ac.uk

SERC is an independent research centre funded by the Economic and Social Research Council (ESRC), Department for Business Innovation and Skills (BIS) and the Welsh Assembly Government. 